\title{
THE USE OF 1-METHYL NAPHTHALENE AS COAL ASH REMOVAL SOLVENT
}

\author{
PENGGUNAAN 1-METIL NAFTALEN SEBAGAI LARUTAN \\ PENGHILANGAN KADAR ABU DALAM BATUBARA
}

\author{
DATIN F. UMAR and GANDHI K. HUDAYA \\ R\&D Centre for Mineral and Coal Technology \\ Jalan Jenderal Sudirman 623 Bandung 40211 \\ Phone (+6222) 6030483, Fax. (+6222) 6003373 \\ e-mail: datinf@tekmira.esdm.go.id
}

\begin{abstract}
Solvent extraction method is one of the methods to reduce ash content in coal to improve the energy efficiency and reduce negative environmental impacts. The use of 1-methyl naphthalene (1-MN) as a solvent in the weight ratio of coal to solvent of 1: 3, 1: 6 and 1: 9 using three coal samples obtained from a coal washing plant, namely ROM (run of mine), DC (dirty coal) and RC (reject coal) was performed. Results show that the ash content of the extracted coals no or significantly low amount $(<0.3 \%)$ ash contents. The highest extraction yield was obtained at $15.38 \%$ (daf) at DC coal sample and coal to solvent ratio of 1:9, while the lowest at $3.09 \%$ (daf) at ROM coal sample and coal to solvent ratio of 1:3. In addition, the extraction process with a solution of 1-MN also able to reduce moisture content of the coals, as a result the calorific value of the coals were significantly increased.
\end{abstract}

Keywords: solvent, ash, extraction yield, moisture, calorific value

\begin{abstract}
ABSTRAK
Metode ekstraksi pelarut merupakan salah satu metode untuk mengurangi kadar abu dalam batubara sehingga meningkatkan efisiensi energi dan mengurangi dampak negatif terhadap lingkungan. Penelitian penggunaan 1-metil naftalen (1-MN) sebagai pelarut dengan rasio antara batubara dan pelarut 1: 3, 1: 6 dan 1: 9 dengan menggunakan tiga buah contoh batubara yang diperoleh dari pabrik pencucian batubara, yaitu ROM (run of mine), DC (dirty coal) dan RC (reject coal) telah dilakukan. Hasil penelitian menunjukkan bahwa kadar abu batubara hasil ekstraksi tidak ada atau sangat rendah $(<0,3 \%)$. Perolehan tertinggi sebesar 15,38\% (daf) diperoleh pada contoh batubara DC dengan rasio antara batubara dan pelarut 1: 9, sedangkan perolehan terendah pada 3,09\% (daf) untuk contoh batubara ROM dengan rasio batubara dan pelarut 1: 3. Selain itu, proses ekstraksi dengan larutan 1MN juga mampu mengurangi kadar air dari batubara, sehingga nilai kalori batubara meningkat secara signifikan.
\end{abstract}

Kata kunci: pelarut, abu, perolehan, kadar air, nilai kalor

\section{INTRODUCTION}

The Indonesian Government has set an ambitious target to add approximately $35,000 \mathrm{MW}$ installed power generation within a period of 5 years (2014-2019). With a projected economic growth of 6-7 percent a year, additional electricity capacity in this country needs at least 7,000 MW per year. Approximately about $25,000 \mathrm{MW}$ of the project will use coal as fuel. This project has been confirmed in the document of the National Medium Term Development Plan (Anonymous, 2014).

Coal was selected as a source of electricity due to the price of coal is cheaper than diesel. However, there are some consequences of the use of coal, specifically the environmental problem of pollution and emissions. The main problem associated with the environment in the coal is ashes. Coal 
ash is the waste that is left after coal is burned in coal-fired power plants. It includes fly ash, bottom ash, boiler slag, flue gas desulfurization residue and other solid fine particles which possess major environmental problems. Depending on where the coal was mined, coal ash typically contains heavy metals including arsenic, lead, mercury, cadmium, chromium and selenium, as well as aluminum, antimony, barium, beryllium, boron, chlorine, cobalt, manganese, molybdenum, nickel, thallium, vanadium, and zinc. Arsenic is one of the most common, and most dangerous (Pandey et al., 2011).

Most of Indonesia's coal resources, the ash content is low (generally $<10 \%$ ). However, in some areas the ash content in coal is relatively high so it needs to be washed. In addition, during the process of mining, a portion of the roof and floor material may be taken along with the coal seam in order to create adequate working height for the equipment and miners. The position of the coal at the roof or bottom layer usually has high ash content due to contamination of overburden (Ghasemi et al., 2014).

It is also necessary to remove the ash from coal to be combusted directly in the new generation integrated gas combined cycle (IGCC) gas turbines to overcome issues like erosion and corrosion of turbine blade and fouling due to coal ash deposition. Thus, it is advantageous to upgrade coals in terms of ash and moisture contents. A new costeffective and efficient process is therefore essential to remove the ash and upgrade the low-rank lignite and sub-bituminous coals. One such technology could be the production of ash-free coal (AFC). It could be a preferred feed for some applications, such as direct combustion in the gas turbines (Okuyama, et al., 2004). Utilization of AFC directly in a gas turbine as fuel can generate a power system of higher thermal efficiency without damaging the turbine blades (Wijaya and Zhang, 2011).

From those point of views, the ash content in coal should be minimized. The reduction/ removal of ash content has been implemented in coal washers in Indonesia as pre-combustion clean coal technology. The choice of process depends on factors such as the type of coal being treated, the market requirement and the economics. The washed coal is expected to have a low ash content. If the raw coal has high ash content, thereof the yield is low. In the coal washing plant, approximately $30 \%$ of which is reject coal, because of the very high ash content. Consequently, the reject coal would be excessive. The disposal of this huge quantity of rejects in an environment friendly manner poses a real problem.

The reject coal that has high contain of ash, could be further processed through ash removal using solvent. There are two main types of chemical treatment of coals to produce clean coal. The first one, aiming to produce the upgraded coal using strong acids or alkalis to dissolve all the minerals leaving the organic coal matrix under hydrothermal conditions is termed as ultra clean coal (UCC).The second process uses organic solvents to dissolve organic matter and precipitating back the ash free coal known as hyper-coal (Okuyama, et al, 2004) is termed here as ash free coal (AFC). However, the coal from the UCC process may contain around $0.5 \%$ ash and cannot be directly fired in the gas turbines. Another possible concern could be associated with the corrosiveness and biodegradability of strong acids and alkali reagents used and consequently disposal of the waste solution.

This research was aimed to get the processing condition of ash removal using coals from a coal washing plant in East Kalimantan. According to the previous research (Umar, et al, 2015), to remove the ash content in coal through organic solvent extraction, among the organic solvents of metoxcy etoxcy acetic acid (MEAA), 1-methyl naphthalene (1-MN) and 1-methyl 2pyrolidinon (MP) that have been tested, 1-MN is the best solvent that produces coal with the lowest ash content.

1-MN is a naphthalene-related compound that is also called alpha methyl-naphthalene. It is a clear liquid with the formula of $\mathrm{C}_{11} \mathrm{H}_{10}$ (Hardacre et al, 2010). A naphthalene molecule can be viewed as the fusion of a pair of benzene rings (Figure 1). It is classified as a benzenoid polycyclic aromatic hydrocarbon $(\mathrm{PAH})$ with a density of $1 \mathrm{~g} / \mathrm{cm}^{3}$, molar mass of $142.2 \mathrm{~g} / \mathrm{mol}$, cetane number of zero, and was previously used as the lower reference for cetane number. As derivate of naphtelene, 1-MN provides an excellent solubilizing medium for poorly soluble aromatic compounds. In many cases it is more efficient than other high-boiling solvents, such as dichlorobenzene, 
benzonitrile, nitrobenzene and durene. As a non-polar, 1-MN can solve the polar such ash mineral matter in coal.

Solvent extraction of coal using 1-MN can produce AFC that has significantly much lower ash content than that of the raw coal (Lee, 2012). However, there are some limitations of AFC preparation process, such as low product yield and use of residual coal discharged.
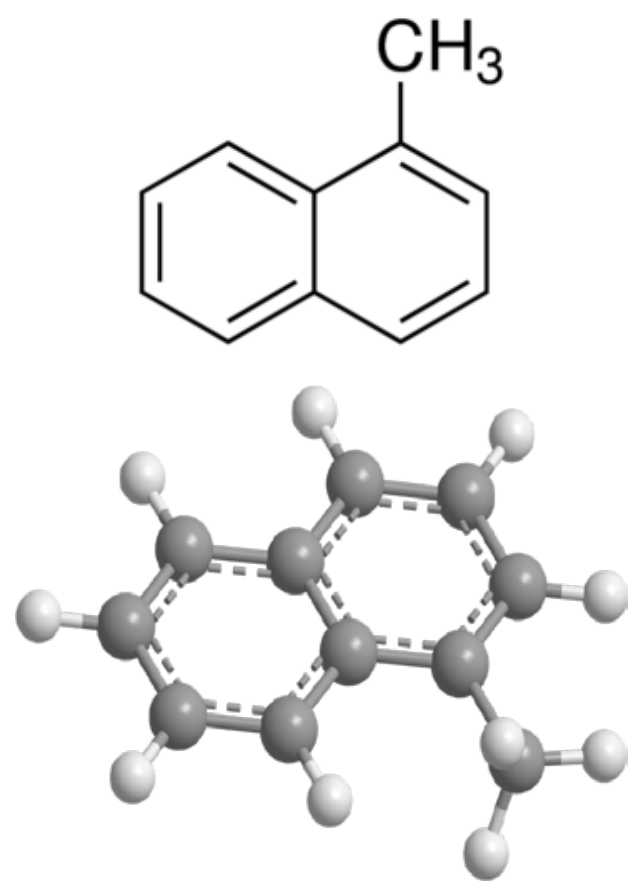

Figure 1. 1-MN chemical structure

From the foregoing discussion, it is found that most of the works on thermal extraction of coal to produce AFC, have been performed using bituminous and sub-bituminous coals from the Australian, Indonesian, South African and American origins (Rahman, et al., 2013, Shui et al, 2013). However, in spite of abundant availability of reject coal from a washing plant, there was no study available in literature for preparation of AFC using industrial solvents, such as heavy aromatic hydrocarbons and hydro treated heavy aromatic hydrocarbons. Therefore, the reject coal also be used as coal itself. Therefore, one of the objectives of this study is to investigate the effect of 1-MN in various concentration through coal to solvent ratio on the extraction yield of extracted coals.

\section{METHODOLOGY}

The raw coal samples were obtained from mining and coal washing plant (CWP) in East Kalimantan. There were run of mine (ROM), dirty coal (DC) and reject coal (RC). To support this research, analysis of inherent moisture, ash, volatile matter, fixed carbon, and calorific value were conducted to the both of coal samples. The result of analyses is given in Table 1.

As explained above, during the process of mining, a portion of the roof and floor material may be taken along with the coal seam, the ROM coal that comes directly from a mine has relatively high ash content of $27.07 \%$ (Table 1). The buyer, on the other hand, may demand certain specifications depending on the intended use of the coal. DC is coal taken from CWP shortly before washing (feed of CWP). This coal has lower ash content compared to the ROM i.e. $25.47 \%$. The lower ash content might be caused by the pre-separation of impurities before going into a washing machine. The $\mathrm{RC}$ is the waste from CWP, including substances such as coal fines, soil, sand, and rock. So that the coal has a very high ash content of $54.66 \%$. This coal is usually discarded and disposed.

Their moisture content is as low as 4.42, 4.89 and $3.05 \%$ respectively of ROM, DC and RC. Despite of low inherent moisture content, the calorific value of the coals are relatively low due to the high of ash content. The calorific value of the RC only $2.843 \mathrm{cal} / \mathrm{g}$.

The coal samples was ground into fine particles of less than $75 \mu \mathrm{m}$ in diameter before being served to the solvent treatment through these steps:

- Coal was dried at $40^{\circ} \mathrm{C}$ in an oven;

- Dried coal crushed using hammer mill to be $2.3 \mathrm{~mm}$ in diameter size.

- Crushed coal ground using rock lab and sieved using 200 mesh sieving to get coal with diameter size of $75 \mu \mathrm{m}$. 
Table 1. Analysis result of raw coal samples in air dried basis (adb)

\begin{tabular}{|c|c|c|c|c|c|}
\hline \multirow{2}{*}{ Parameter } & \multicolumn{3}{|c|}{ Samples mark } & \multirow{2}{*}{ Unit } & \multirow{2}{*}{ Standard Methods } \\
\hline & ROM & DC & $\mathrm{RC}$ & & \\
\hline Inherent moisture & 4.42 & 4.89 & 3.05 & $\%$ & ASTM D.3173 \\
\hline Ash & 27.07 & 25.47 & 54.66 & $\%$ & ASTM D.3174 \\
\hline Volatile matter & 31.61 & 32.06 & 22.43 & $\%$ & ISO 562 \\
\hline Fixed carbon & 36.9 & 37.58 & 19.86 & $\%$ & ASTM D.3172 \\
\hline Calorific value & 5.185 & 5.271 & 2.843 & $\mathrm{cal} / \mathrm{g}$ & ASTM D 5865 \\
\hline
\end{tabular}

A stainless steel vibrating autoclave with a capacity of $500 \mathrm{~mL}$ was used for this experiment (Figure 2). Coal was charged into the autoclave together with 1-MN solvent. The ratios between coal and solvent were $1: 3 ; 1: 6$ and 1:9 wt. \%. After sufficiently purging the autoclave with nitrogen, the coal in the autoclave was heated up to $300^{\circ} \mathrm{C}$ at which it was kept for 1 hour under sufficient agitation (Umar, et al., 2014). Then the coal was separated into residue, filtrate and gaseous product consisting of $\mathrm{CO}_{2}, \mathrm{H}_{2} \mathrm{O}$ and a negligible amount of hydrocarbon gases (Fujitsuka, et al., 2013) at the treatment temperature by opening the valve connecting the autoclave and the reservoir by filtration at room temperature (Figure 3 ). The filtrate was further heated in a vacuum oven to separate extracted coal and solvent fraction. The solvent can be used for the next process. Residues and extracted coals then were dried, weighed and analysed to proximate and calorific value analysis.

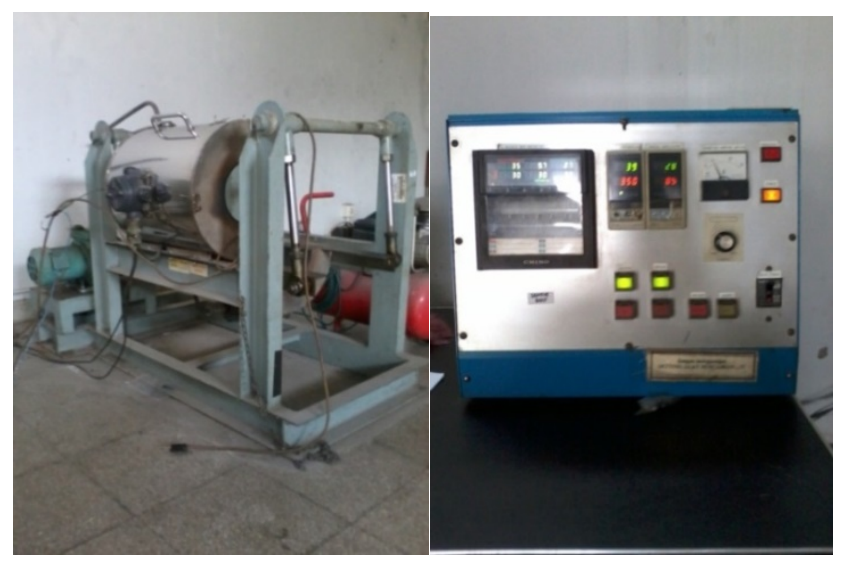

Figure 2. Stainless steel vibrating autoclave

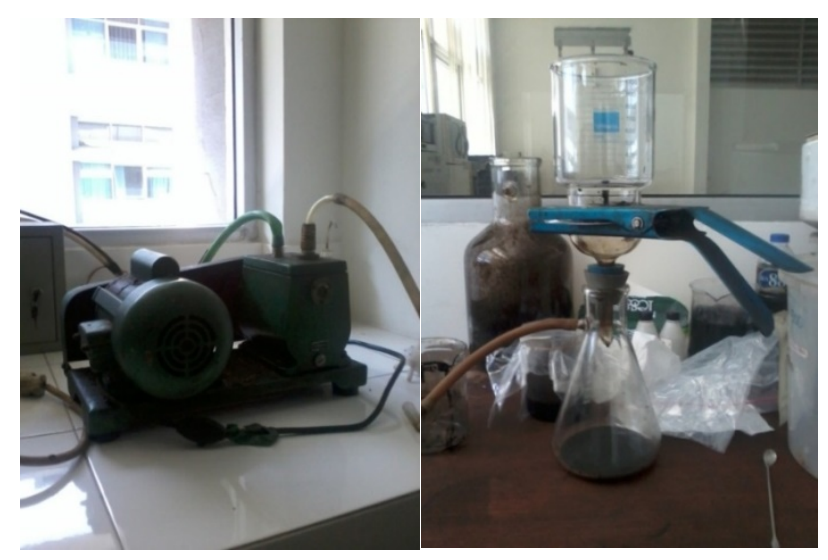

Figure 3. Separation apparatus 
The extraction yield was calculated based on dry ash-free basis (daf) from the weight of dry extracted coal produced using the following Equation (Rahman, et al., 2013).

Extraction yield $(w t \%$, daf $)=\frac{\text { Weight of dry extracted coal }}{\text { Weight of feed coal (daf) }} \times 100 \%$

\section{RESULTS AND DISCUSSION}

The extracted coals and residues were characterized to understand the thermochemical changes occurring before and after the solvent extraction using 1-MN. The result of proximate analysis and calorific value of both can be seen in Table 2 and 3 respectively.

The extracted coals show no or significantly low amount $(<0.3 \%)$ ash contents (Table 2). This is possibly due to the ability of polar components present in the coal being dissolved in non-polar solvent of 1-MN. Okuyama, et al., 2004 reported that 1-MN is an effective recoverable solvent for coal extraction under mild conditions at $202{ }^{\circ} \mathrm{C}$ and atmospheric pressure. The more the addition of 1-MN is not correlated with the decreasing of coal content (Figure 4).
Figure 4 shows that coal to solvent ratio of DC and RC coal samples is not significantly affected on ash content. Nonetheless of ROM. The more the amount of solvent the less the ash content. The DC coal sample with the ratio of coal to solvent of 1:6 has the highest ash content of 0.2 , while the lowest ash content reached by DC and RC coal samples with the ratio of coal of 1:3 and 1:9 respectively. In fact, the ratio of coal to solvent is not affected the ash content of the coal samples, where the ash content for all of the coal samples are very low. So that the difference can be ignored. According to Siefert and Litster, 2013, the ash content of $<0.3 \%$ can be directly fired in the gas turbines of the IGCC.

The use of 1-MN also decreased the inherent moisture content in the extracted coals. As a result the calorific value also increased significantly. The decreasing of inherent moisture is parallel with the coal to solvent ration. The more the 1-MN, the high the moisture content (Figure 5). This occurence could be caused by more and more the water (as a part of the 1-MN) is remained in the extracted coal.

Table 2. Proximate analysis and calorific value of extracted coal (adb)

\begin{tabular}{|c|c|c|c|c|c|c|c|c|c|}
\hline \multirow{3}{*}{ Parameter } & \multicolumn{9}{|c|}{ Sample mark } \\
\hline & \multicolumn{3}{|c|}{ ROM } & \multicolumn{3}{|c|}{$\mathrm{DC}$} & \multicolumn{3}{|c|}{$\mathrm{RC}$} \\
\hline & $1: 3$ & $1: 6$ & $1: 9$ & $1: 3$ & $1: 6$ & $1: 9$ & $1: 3$ & $1: 6$ & $1: 9$ \\
\hline Inherent moisture, \% & 0.30 & 2.87 & 4.83 & 0.25 & 0.33 & 3.81 & 0.37 & 0.53 & 2.59 \\
\hline Ash, $\%$ & 0.18 & 0.27 & 0.05 & 0 & 0.20 & 0.17 & 0.08 & 0.13 & 0 \\
\hline Volatile matter, \% & 62.78 & 63.85 & 59.87 & 70.62 & 66.09 & 61.28 & 62.78 & 62.42 & 63.13 \\
\hline Fixed carbon, \% & 36.74 & 33.01 & 35.25 & 29.13 & 33.38 & 34.75 & 36.81 & 36.92 & 34.28 \\
\hline Calorific value, cal/g & 8,767 & 8,549 & 8,429 & 8,720 & 8,498 & 8,494 & 8,463 & 8,305 & 8,362 \\
\hline
\end{tabular}

Table 3. Proximate analysis and calorific value of residue (adb)

\begin{tabular}{|c|c|c|c|c|c|c|c|c|c|}
\hline \multirow{3}{*}{ Parameter } & \multicolumn{9}{|c|}{ Sample mark } \\
\hline & \multicolumn{3}{|c|}{ ROM } & \multicolumn{3}{|c|}{$\mathrm{DC}$} & \multicolumn{3}{|c|}{$\mathrm{RC}$} \\
\hline & $1: 3$ & $1: 6$ & $1: 9$ & $1: 3$ & $1: 6$ & $1: 9$ & $1: 3$ & $1: 6$ & $1: 9$ \\
\hline Inherent moisture, \% & 6.46 & 5.92 & 5.38 & 9.00 & 7.45 & 7.24 & 6.31 & 5.04 & 4.03 \\
\hline Ash, \% & 28.04 & 28.06 & 27.59 & 21.20 & 24.06 & 20.40 & 56.2 & 55.52 & 56.39 \\
\hline Volatile matter, \% & 37.32 & 37.77 & 38.72 & 37.15 & 38.15 & 41.80 & 21.49 & 23.83 & 24.68 \\
\hline Fixed carbon, \% & 28.18 & 28.25 & 28.31 & 32.65 & 30.34 & 30.56 & 16.00 & 15.61 & 14.90 \\
\hline Calorific value, cal/g & 5,613 & 5,708 & 5,712 & 6,213 & 5,999 & 6,297 & 3,109 & 3,178 & 3,161 \\
\hline
\end{tabular}




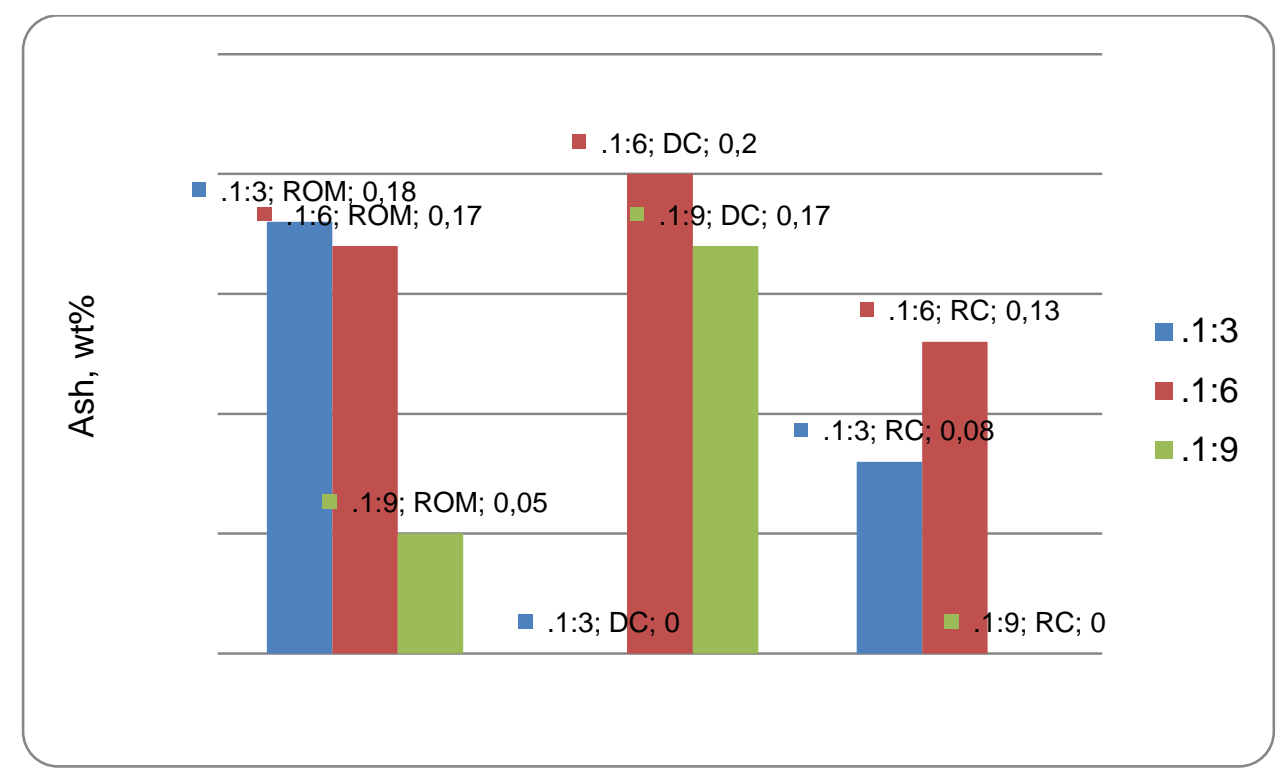

Figure 4. The effect of coal to solvent ratio on ash content of extracted coal

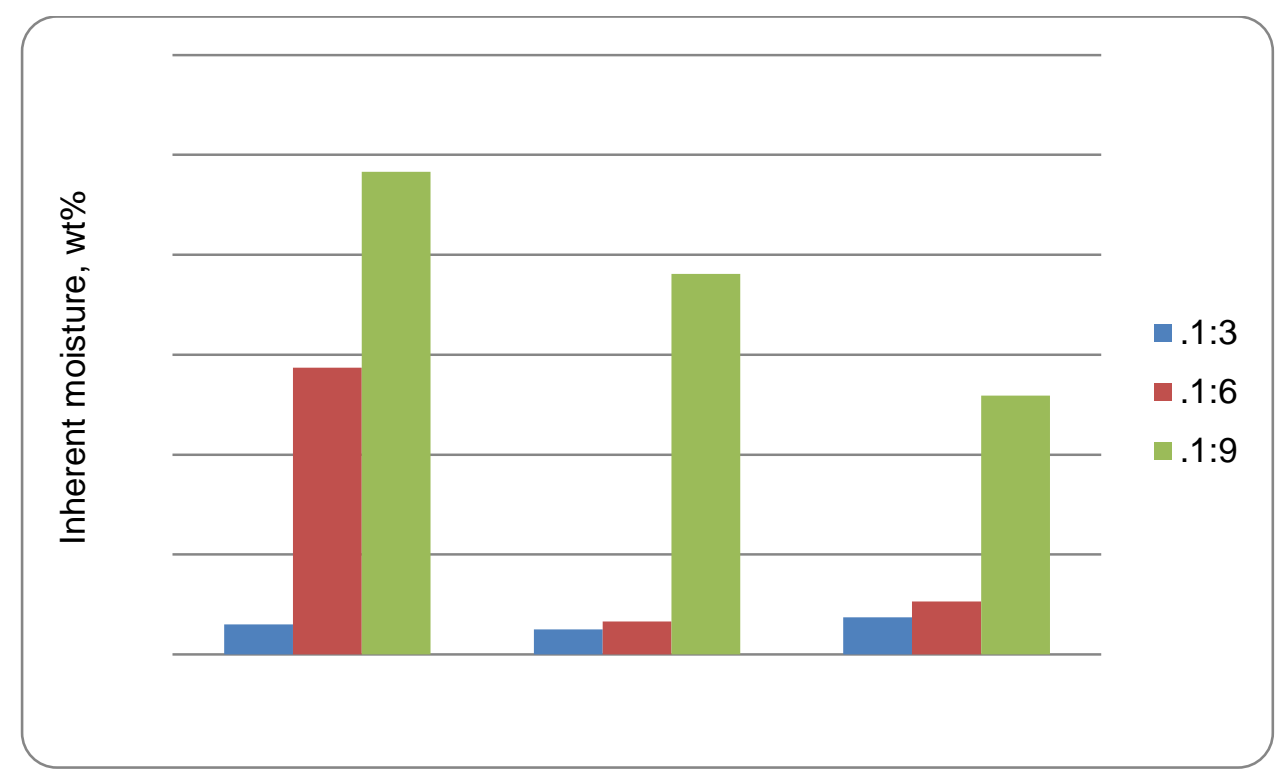

Figure 5. The effect of coal to solvent ratio on moisture content of extracted coal

Different with moisture content, the calorific value of the extracted coal are not directly correlated in line with the coal to solvent ratio (Figure 6). The calorific value of the ROM and DC extracted coals decreased due to the increasing of coal to solvent ratio, in line with the increasing of inherent moisture. While the RC extracted coal, the calorific value of the extracted coal in the ratio of $1: 6$ is the lowest parallel with the highest ash content of the coal.
In the residue fraction, the ash content of ROM and RC increased while the ash content of DC decreased (Table 3). The increasing of the ash content indicating the possible enrichment of heavy aromatic hydrocarbon components in those residue coals. The increasing of moisture content indicating the enrichment of the hydrogen in the hydrocarbon components. Consequently the calorific value of the residues are higher compared with the corresponding raw coals. 
Similar observations were also reported by Takanohashi et al. 2008.

As can be seen in Table 4 above, the extraction yield relatively low between 3.09 and $15.38 \%$ daf. However, the rate of the extraction yield increases rapidly with the increase of coal to solvent ratio (Figure 7).
This is possibly due to the enhanced coal and solvent interaction and consequently, higher solvent induced thermal relaxation of coal molecules is occurring and releasing mainly small molecules and free radicals from the cross-linking coal structure to the solvent (Sonmez and Giray, 2011).

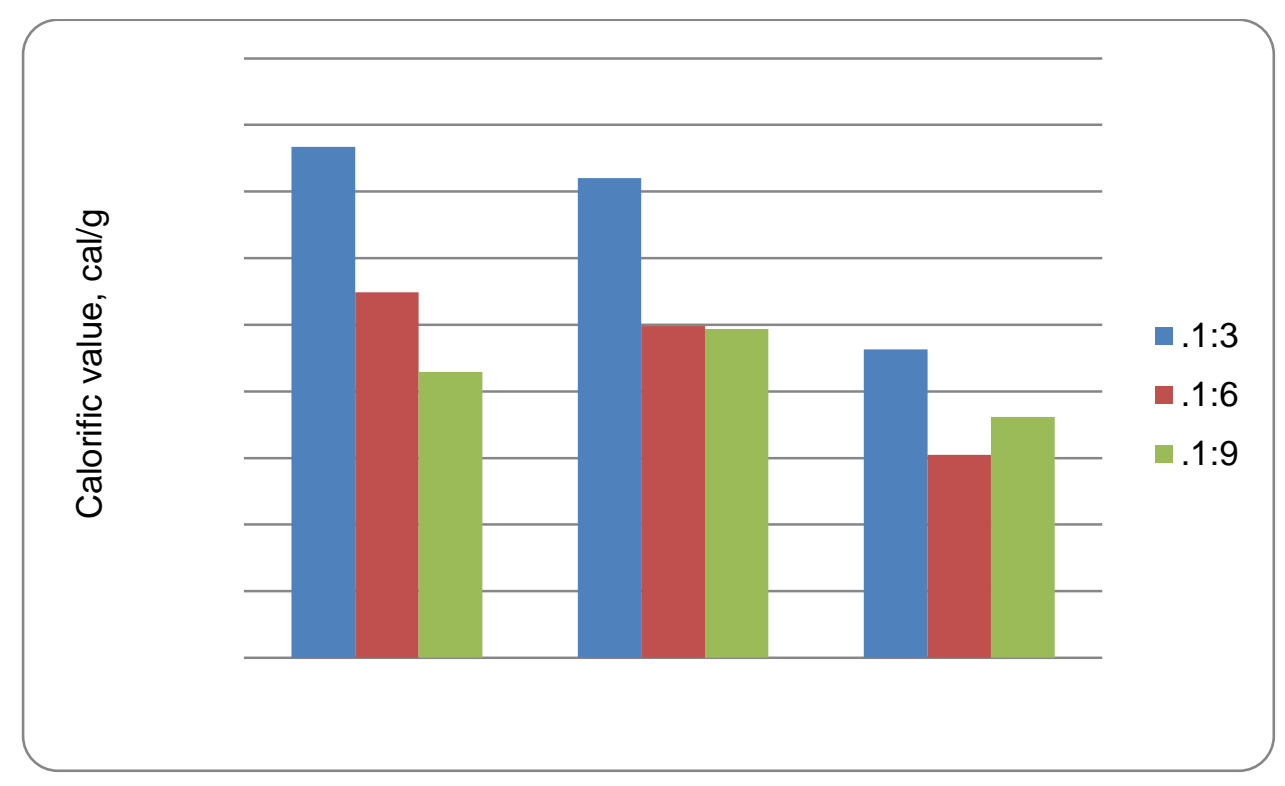

Figure 6. The effect of coal to solvent ratio on calorific value of extracted coal

Table 4. Extraction yield of 1-MN treatment

\begin{tabular}{cccc}
\hline $\begin{array}{c}\text { Coal sample/coal to } \\
\text { solvent ratio }\end{array}$ & $\begin{array}{c}\text { Coal initial weight } \\
\text { g, dry ash free }\end{array}$ & $\begin{array}{c}\text { Extracted coal } \\
\text { g, dry }\end{array}$ & $\begin{array}{c}\text { Extraction yield } \\
\text { \%, dry ash free }\end{array}$ \\
\hline ROM & & & \\
$1: 3$ & 17.13 & 0.53 & 3.09 \\
$1: 6$ & & 1.21 & 7.09 \\
$1: 9$ & & 1.57 & 9.17 \\
\hline DC & & & \\
$1: 3$ & \multirow{2}{*}{10.57} & 0.43 & 4.06 \\
$1: 6$ & & 1.36 & 12.82 \\
$1: 9$ & & 1.63 & 15.38 \\
RC & \multirow{3}{*}{17.41} & 0.56 & 3.20 \\
$1: 3$ & & 0.72 & 4.11 \\
$1: 6$ & & 1.05 & 6.04 \\
\hline $1: 9$ & & &
\end{tabular}




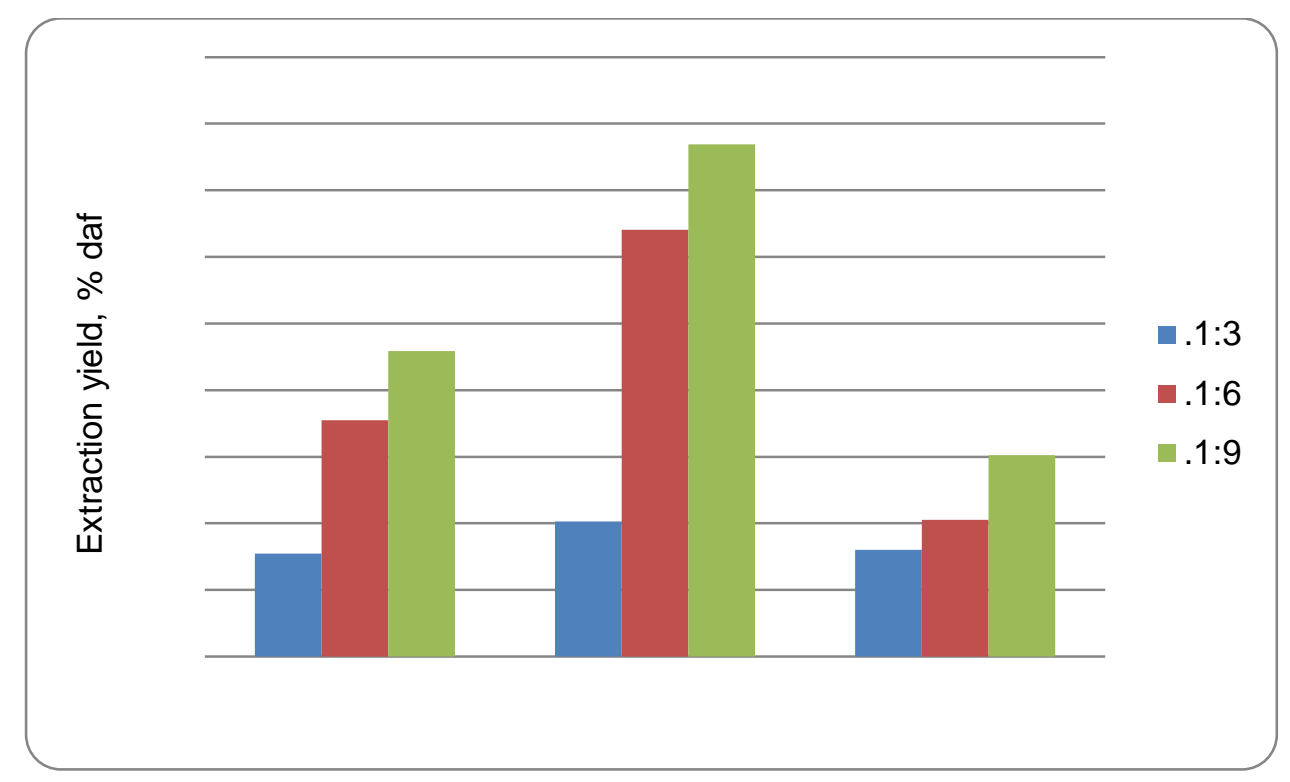

Figure 7. Effect of coal to solvent ratio on the extraction yield using 1-MN

The highest extraction yield was obtained at $15.38 \%$ (daf) at DC coal sample and coal to solvent ratio of 1:9. Rahman, et al., 2011, reported the extraction yield by using Canadian coal and 1-MN as solvent was $2.6 \%$ at temperature of $200^{\circ} \mathrm{C}(473 \mathrm{~K})$ and $31.3 \%$ at temperature of $300^{\circ} \mathrm{C}(673 \mathrm{~K})$. Okuyama et al., 2004 investigated 20 different coals of Chinese origin mainly bituminous and extracted with 1-MN. The extraction yields were within the range 30$70 \%$ at $633 \mathrm{~K}$ and these yields were largely dependent on the coal characteristics. They found that the extraction yield of brown coals is less than $30 \%$ (daf) and Algerian subbituminous coal was maximum $47 \%$ at $300^{\circ} \mathrm{C}$. The low extraction yield, one possible reason could be the loss of significant amount of gaseous products from high oxygen containing reactive coals during high temperature soaking period in the reactor. Besides, the extracted coal liquid may have some soluble components that may dissolve in solvent and does not tend to precipitate upon dilution. It is also possible that low molecular weight volatile components present in the extracted coal liquid may be lost due to natural evaporation. Consequently, it produces less extracted coal yields. The new study of Okuyama, et al., 2014, heating rate affected on the coal extraction yield and the property of the extraction products. The rapid heating, higher than $1000^{\circ} \mathrm{C} / \mathrm{min}$ of heating rate, improved coal extraction yield compare to the conventional heating, lower than $100^{\circ} \mathrm{C} / \mathrm{min}$. This effect appeared with the coal which had lower extraction yield by the conventional heating.

The extraction yields of RC extracted coal are the lowest compare with that of the extracted coals of ROM and DC at a same treatment condition (Figure 8), except for the $\mathrm{RC}$ at the ratio of coal to solvent $1: 3$, the extraction yield of the RC is slightly higher than that of the ROM coal. It could be understood, because the RC raw coal has a very high ash content, and mostly inherent impurities that consisting of organic constituents that previously formed part of the tissues of the plants from which the coal was derived. Most impurities is chemically or colloidally combined with coal substance ( $\mathrm{Li}$ et al., 2014). 


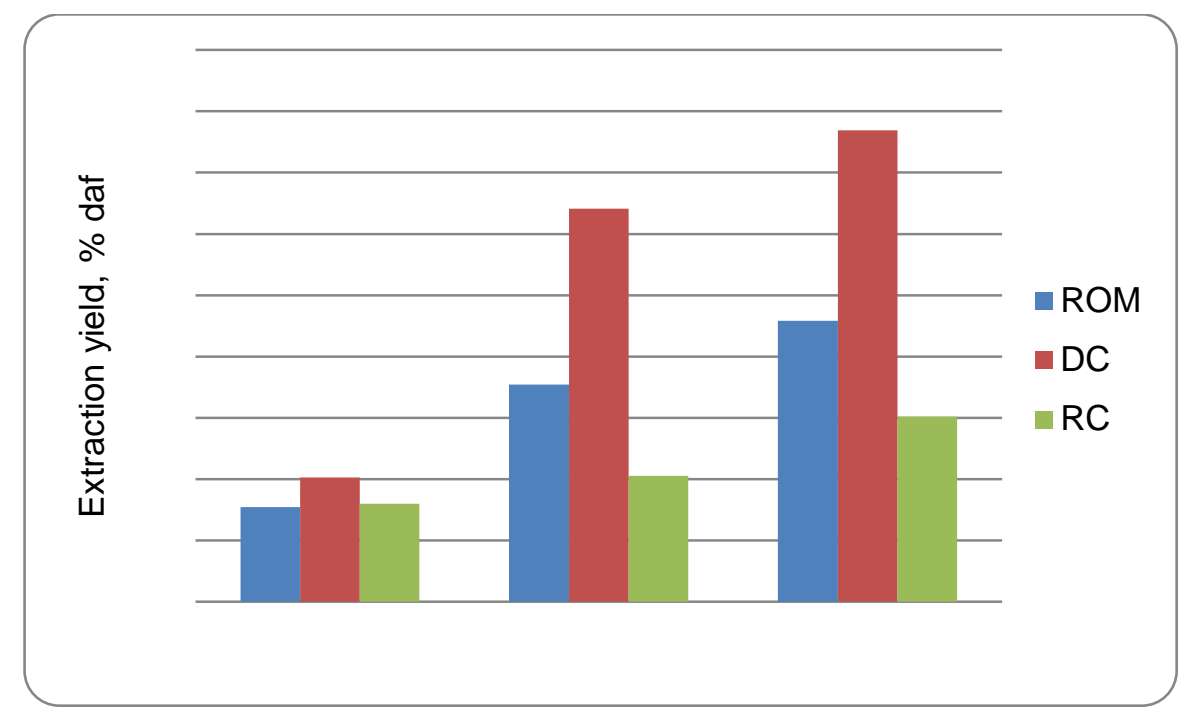

Figure 8. Effect of coal sample type on the exraction yield using 1-MN

Low extraction yield, remained high residues. Rom and DC residues which have ash content of about 28 wt $\%$ and 21 wt \% respectively (Table 3 ). But, since the residual coal with high ash content contains low moisture (less than 10\%) and it has high calorific value of more than $5,600 \mathrm{cal} / \mathrm{g}$, the residues can be utilized effectively for power generation or steam generation using fluidized bed combustors. The residue coals also have high reactivity and can be used as reducing agent in the synthetic rutile production from ilmenite resources (Komatsu, et al., 2009). Beside that, the residues could be returned to the coal mining in a lower price and/or recycled again to the coal washing plant. There is a lot of example that coal washed residue is sold about half of the price (Okuyama, et al, 2004)

\section{CONCLUSIONS}

Solvent extraction of three coal samples obtained from a coal washing plant, namely ROM (run of mine), DC (dirty coal) and RC (reject coal) was performed using 1-Methyl Naphtalene (1-MN). The effect of coal to solvent ratio on preparing extracted coals was examined. The following conclusions were obtained:

- The ash content of the extracted coals shows no or significantly low amount $(<0.3 \%)$ ash contents. This is possibly due to the ability of polar components present in the coal being dissolved in non-polar solvent of 1-MN.
- The highest extraction yield was obtained at $15.38 \%$ (daf) at DC coal sample and coal to solvent ratio of $1: 9$, while the lowest at $3.09 \%$ (daf) at ROM coal sample and coal to solvent ratio of $1: 3$

- The low extraction yield, one possible reason could be the loss of significant amount of gaseous products from high oxygen containing reactive coals during high temperature soaking period in the reactor. While the extraction yield increases with increasing coal to solvent ratio.

- The extraction process by using 1-MN also able to reduce moisture content and the calorific value of the coals were significantly increased.

- The residue will be returned to the coal mining and/or recycled again to the coal washing plant. The calorific value of more than $5,600 \mathrm{cal} / \mathrm{g}$ is acceptable to be utilized as the fuel for power plant

\section{ACKNOWLEDGEMENT}

The authors gratefully acknowledge the head of R\&D Center for Mineral and Coal Technology (tekMIRA) for making this research possible. We are also expressing our deep gratitude to PT Kaltim Prima Coal (PT KPC) for their full support during coal sampling. Thanks also go to the staffs of coal laboratory of tekMIRA for their full assistance during laboratory works. 


\section{REFERENCES}

Anonymous, 2014. Rancangan Awal Rencana Pembangunan Jangka Menengah Nasional 2015-2019, Buku I Agenda Pembangunan Nasional, Kementerian Perencanaan Pembangunan Nasional/ Badan Perencanaan Pembangunan Nasional, Republik Indonesia.

Fujitsuka, H., Ashida, R. and Miura, K., 2013, Upgrading and dewatering of low rank coals through solvent treatment at around $350^{\circ} \mathrm{C}$ and low temperature oxygen reactivity of the treated coals, Fuel, vol. 114, p.16-20.

Ghasemi, J., Karamoozian, M. and Sereshki, F., 2014. Investigation of different coal types effect on the overall plant recovery, International Journal of Mining Science and Technology, vol. 24 (4), p. 447-450.

Hardacre C, Holbrey JD, Mullan CL, Nieuwenhuyzen M, Youngs TG, Bowron DT. and Teat SJ, 2010. Solid and liquid charge-transfer complex formation between 1-methylnaphthalene and 1alkyl-cyanopyridinium bis\{(trifluoromethyl)sulfonyl\}imide ionic liquids, Biodegradation. 21 (2), p. $267-$ 81. DOI: $10.1007 / \mathrm{s} 10532-009-9299-2$.

Komatsu, N., Okuyama, N. and Hamaguchi, M., 2009. Application of ash free coal for reduction of nonferrous metal, Sekitan Kagaku Kaigi Happyo Ronbunshu, 46, p. 18-19.

Lee, Sihyun, 2012. Current R\&D Status of Low Rank Coal Utilization in Korea. APEC Symposium on Energy Efficiency of Low Rank Coal.

Li, X., Zhu, X.Q., Xiao, L.a, Ryuichi, A., Kouichi, M., Luo, G.-Q. and Yao, H., 2014. Degradative solvent extraction of demineralized and ion-exchanged lowrank coals, Ranliao Huaxue Xuebao/Journal of Fuel Chemistry and Technology, vol. 42 (8), p. 897-904.

Okuyama, N., Komatsu, N., Shigehisa, T., Kaneko, T. and Tsuruya, S., 2004, Hyper-coal process to produce the ashfree coal, Fuel Processing Technology, vol. 85 ( 6-10), p. 947-967.

Okuyama, N. , Sakai, K., Kinoshita, S., Yoshida, T., Hamaguchi, M. and Kikuchi, N., 2014. Influence of the rapid heating process on coal extraction yield and properties, Conference Paper 31st Annual International Pittsburgh Coal Conference: Coal - Energy, Environment and Sustainable Development, Pittsburgh; United States; Code 110055

Pandey, V.C., Singh, J.S., Singh R.P., Singh, N. and Yunus, M., 2011. Arsenic hazards in coal fly ash and its fate in Indian scenario, Resources, Conservation and Recycling, vol. 55, p. 819-835.

Rahman, M., Samanta, A., Klerk, A.D. and Gupta, R., 2011. Ash-free coal (AFC) from low-grade Canadian coal by solvent extraction, Preprints of Papers, American Chemical Society, Division of Fuel, vol. 56 (2), p. 308-309.

Rahman, M., Samanta, A., Gupta, R., 2013. Production and characterization of ashfree coal from low-rank Canadian coal by solvent extraction, Fuel Processing Technolog ,vol. 115, p. 88-98.

Shui, H., Zhou, Y., Li, H., Wang, Z., Lei, Z., Ren, S., Pan, C. and Wang, W., 2013. Thermal dissolution of Shenfu coal in different solvents, Fuel, vol.108, p. 385-390.

Siefert, NS. and Litster S., 2013. Exergy and Economy Analyses of Advanced IGCCCCS and IGFC-CCS Power Plants, Applied Energy 107, p. 315-328.

Sonmez, O. and Giray ES., 2011. Producing ashless coal extracts by microwave irradiation, Fuel, vol. 90, p. 2125-2131.

Takanohashi, T., Shishido, T., Kawashima H. and Saito, I., 2008. Characterisation of Hypercoals from Coals of Various Ranks, Fuel, vol. 87 (4-5), p. 592-598.

Umar, DF., Hudaya, GK., Sulistyohadi, F., Rahayu, A. dan Susanti, I., 2014, Penurunan Kadar Abu Batubara, Laporan Intern Puslitbang Teknologi Mineral Dan Batubara.

Umar DF., Soelistyohadi, F., and Hudaya, G.K., 2015. Coal De-Ashing by Solvent Extraction, Indonesian Mining Journal, vol. 18 (1).

Wijaya, N. and Zhang, L., 2011. A critical review of coal demineralization and its implication on understanding the speciation of organically bound metals and sub-micrometer mineral grains in coal, Energy \& Fuels, vol. 25, p. 1-16. 